\title{
Sociocultural and Linguistic Reflections on Post-colonial Studies of H.K. Bhabha
}

\author{
Alexandra Milostivaya ${ }^{1, *}$, Ekaterina Nazarenko $^{1}$, Irina Makhova ${ }^{2}$, and Armine Simonyan ${ }^{3}$ \\ ${ }^{1}$ North-Caucasus Federal University, Department of Translation Studies, 355009 Pushkin Street 1 Stavropol, Russian Federation \\ ${ }^{2}$ Stavropol State Agrarian University, Department of Foreign Languages, 355017 Zootechnicheskiy Ln 12 Stavropol, Russian \\ Federation \\ ${ }^{3}$ Russian-Armenian University, Department of Theory of Language and Cross-Cultural Communication, 0051 Hovsep \\ Emin Street 123 Yerevan, Armenia
}

\begin{abstract}
The article is devoted to the socio-cultural and linguistic analysis of the postcolonial theory of H.K. Bhabha, who attempted to explain the colonial discourse, based on the concepts of "hybrid space" and "the phenomenon of mimicry" in his work "The Location of Culture" (1994). According to him, the colonial discourse is a complex, ambivalent and often contradictory process. The movement in time and space does not allow different identities become frozen in the unity of opposite. The difficulty lies in the exact definition of hybridity, understood as a boundary between the fixed identities. Particular attention is paid to the interpretation of the concept of translation of H.K. Bhabha, who believes that the translational process goes through some previously established boundaries and therefore puts them into question. H.K. Bhabha argues that the process of translation leads to hybridity codes and verbal propositions, actualizing their semantics in the socio-cultural situation of the target language. In addition, the focus of research interest of the authors got some lexical and grammatical features of the monograph "The Location of Culture" as a representative sample of the type of the humanitarian scientific style with a primarily cognitive-dominant. Keywords: Post-colonial studies, H.K. Bhabha, monograph "The Location of Culture", translation, primarily cognitive text
\end{abstract}

\section{Introduction}

Post-colonial discourse is still poorly understood in Russia, although it is an integral part of the world of philosophical and sociological thought in the era of globalization [1]. Postcolonial studies emerged and began to develop rapidly since the late 1980s to mid-1990s. It is an interdisciplinary field of science that is devoted to the study of the imperial and colonial heritage of modern society. The focus of the postcolonial discourse analysts' arguments is about "Self" and "Other", which intersect with racial, ethnic and gender projects.

In general, the post-colonial discourse is related to the cultural tradition of the Anglophone and the Francophone part of the world, which has a rich colonial history, but there is a tendency to transfer this local civilizational experience for the whole world. Researchers point out and comprehensively study certain sociocultural universals that are applicable to any human communities, emerged the colonial imperial period in the history. For the post-colonial discourse theory, it is relevant to emphasise the symbiosis and synergy of cultures of the colonizer and the colonized, that can manifest itself in various forms - from hybrid to mimicry and transculturation.

The urgency of this article is determined, above all, by the fact that the focus of our research interest falls on a wide range of social and cultural aspects related to the description of the structure and functions of the post-colonial discourse, as well as a number of linguistic features of this type of verbal communication. In addition, in the modern research tradition, the appellation to the post-colonial discourse, is the contextual framework of the concept of translation. Studies in this area involved scientists such as M. Agar [2], P.F. Bandia [3], S. Bassnett [4-5], E. Federici [6], F. Kalua [7], I.P. Fernándes [8], G.K. Bhambra [9], R. Young [10], T. Shamma [11] etc., as well as Homi K. Bhabha, which will be discussed in this article.

Homi K. Bhabha is one of the leading contemporary philosophers, sociologists and theorists of translation. He is a professor of English and American Literature, a Director of the Humanitarian Center at Harvard University (USA). H.K. Bhabha is an author of numerous works devoted to the problems of post-colonial theory, cultural change and power of contemporary art and cosmopolitanism, among them the book "Nation and Narration" and "The Location of Culture". H.K. Bhabha holds honorary degrees from the University of Paris VIII, University College London, the Free University of Berlin. In 2012, he was awarded the highest state award of Padma Bhushan India in the field of literature and education. In 2015, he was awarded the "Humboldt Research Prize". His main work is the

\footnotetext{
*Corresponding author: xyscha@mail.ru
} 
monograph "The Location of Culture" [12] that will be discussed in this article.

\section{Material and methods}

As research material, we used texts of post-colonial studies of H.K. Bhabha that was quoted by historians, philosophers, linguists and cultural experts. He is one of the most important figures in contemporary post-colonial studies and he developed a number of neologisms and key concepts such as hybridity, mimicry, differences and duality. In his works, H.K. Bhabha affects a variety of issues: the nature of the phenomenon of colonialism, the mechanisms of domination and subordination within it, the concept of multiculturalism, gender and linguistic issues. The sample size was 285 units and 125 terminological typical idiostyles of H.K. Bhabha's syntax (aposiopesis, parenthentic constructions).

The main research method is the method of hermeneutic interpretation of units at different levels of the language system, referred to the features of idiostyle of H.K. Bhabha's scientific discourse. Other methods of research are needed to include:

1. The component analysis to justify the existence and interpretation of discursive specificity of H.K. Bhabha's terminal system;

2. transformational analysis for explication and systematization of H.K. Bhabha's idiostyle, at the level of the grammatical system.

In addition, a number of traditional general scientific research methods was used in the article, such as induction, deduction, observation, classification, generalization.

\section{Results and Discussion}

At first, I would like to say a few words about Post-colonial studies as a general scientific doctrine. Britain has significantly expanded its empire during the XIX century. and firmly consolidated its position in the new territories. These areas are divided into two types such as Canada, New Zealand and Australia, where the British Empire planted its own traditions and practices by relatively peaceful means, and such as India and Nigeria, where violence and imposition of their rules acted as the main monitoring tool. The period of self-determination and the restoration of political independence of the countries of the British Empire was named post-colonial. In the last decades of XX century, the term "postcolonialism" has been extended and furthermore, it eclipsed terms such as postmodernism, poststructuralism and etc. [13].

Processes that took place in the world approximately in the 60s of the XX century (such as the destruction of the great European empires and their replacement by the global economic hegemony of the United States, permanent erasure of national states and traditional geopolitical boundaries, along with mass global migration and the creation of multiethnic communities, increased exploitation in the West and in the "peripheral" societies, the concentration of power in the hands of new multinationals), entered the circle of interests of representatives of post-colonial theory that has been developed primarily in the US and UK universities. In parallel with the mentioned processes, there is a revolution in human understanding of the history of space and space history, government, language, identity [14].

The term "post-colonial" was used in the 70s of the last century to refer to the issues related to the restoration of independence in the world. It has both historical and ideological values. Post-colonialism is a critical theory, which aims to study the colonization process from the point of view of the colonized societies.

Post-colonialism comes to national culture after liberation from imperial power, its myths and history, language and landscape. During the period of Post-colonial studies, the research focus has shifted from Europe to the whole world. Countries such as India, Pakistan, Sri Lanka and other Asian countries, Nigeria, Canada, Australia, South Africa and many Islamic countries have come to the fore in the post-colonial studies.

The post-colonial period means the period that begins with the acquisition of national independence from the rule of the colonialists. Due to the fact that the colonial era is over, by definition, the whole world should be regarded as a post-colonial, but in reality, it is just a continuation of colonialism in a disguised form. Imperial influence is still alive and active today in the cultural sphere of humanity. India could be a post-colonial although formally independent, and at the same time, neocolonial from a psychological point of view. Although it gained independence and freedom from British rule, colonialism remains in its psychology [15].

Most of H.K. Bhabha's works reveals the problem of a continuous process of cultural formation of mutual relations, suffering from the inevitable political [11]. H.K. Bhabha draws attention to the fact that a culture is always a complex mix of disparate parts, a "cultural hybrid" having so-called "cultural polyphony". Thus, H.K. Bhabha articulates the main interest in his research as a process of the boundaries between cultures, the fight against "cultural polyphony" and the formation of cultural identity. One of the main concepts of H.K. Bhabha a is a hybrid. Hybridity is a term used to describe specific cultural objects appearing at the junction of the colonial (European, global) and local traditions.

H.K. Bhabha defines the nature of the colonized in a split the world around as "mimicry", which sets the vision of the colonized and the colonizer. Due to the absence of clearly defined identity markers, the colonized always acts as almost the same as a colonizer, but a little different. The colonizer himself strives to this state. He is ruled by a desire to become the same as the colonizer [12].

The colonial and post-colonial processes contribute interlingual and cross-cultural interaction, that, somehow, makes it necessary to resort to a translation problem. The idea of "cultural translation" is described by H.K. Bhabha in the chapter entitled "How Newness Enters the World: Postmodern Space, Postcolonial Time and the Trials of Cultural Translation" in his main work "The Location of Culture". This chapter is devoted to the interpretation of the novel "The Satanic Verses" by Indian writer Salman Rushdie.

H.K. Bhabha writes about the impact of migrant discourse on European culture and distinguishes two hypotheses on the possible further developments: a migrant behaviour remains unchanged, or it will be a secondary 
process of acculturation. H.K. Bhabha uses such logic for the translation analysis. $\mathrm{He}$ allocates the following opposition where contrasts take place with the translation as a form of a source text and translation as part of the new cultural environment [12].

H.K. Bhabha especially emphasizes the hybrid translation. This concept helps to reveal the status of interpreters who speak two or more languages and familiar with multiple cultures. In addition, this concept makes it possible to explain the main consequences of the transition from one cultural environment to another. H.K. Bhabha does not claim that the translations have a hybrid nature. However, the transfer process itself may cause hybridity as one of their consequences [12]. Thus, H.K. Bhabha considers the translation process to pass through some previously established boundaries and raises the question of their ontological essence. This interpretation helps to reveal some aspects of translation such as a special kind of social and cultural activities, which have not been considered in translatology until now.

Next, we turn to the characteristics of the language and the style of the monograph by H.K. Bhabha, "The Location of Culture". The monograph is a scientific work devoted to the study of one problem, one question. This type of text refers to the scientific type of text for a number of reasons. For example, the most important difference of scientific texts is the prevalence of cognitive information on other types of information. This characteristic determines the consistency of the text: from the description of the existing views, with direct citation to the formulation of a summary at the end of each paragraph, enclosed in a frame:

Therefore, the suggestion that a crisis of identification is initiated in the textual performance that displays a certain 'difference' within the signification of any single political system, prior to establishing the substantial differences between political beliefs [12].

This example is characterized by the logical construction of statements using a lexical connector as "therefore", which makes the transfer of cognitive information most effectively.

With regard to other types of information, including emotional information in scientific text, they are reflected by using the lexical emotionally and assessment tools that were used to transfer the reader installation assessment, i.e. widely accepted, settled views on any phenomenon or process:

There is a damaging and self-defeating assumption that theory is necessarily the elite language of the socially and culturally privilege [12].

In this example, we can observe the transfer of the already established conventional wisdom of the theory for the cultural and social elite, which is made with the help of lexical emotional assessment tools, such as "damaging and self-defeating".

Another characteristics of scientific text, including a monograph, is the use of various graphical tools. For example, the author can use bold in the formulation of the main provisions or definitions. Examples are provided in a smaller font. In the following example, the author uses a bold font for the main discharge of its contents in the utterance:
Forms of popular rebellion and mobilization are often most subversive and transgressive when they are created through oppositional cultural practices [12].

The text of H.K. Bhabha's monograph has no old vocabulary (historicism, archaisms) and spoken vocabulary (dialects). However, as the author of the text is a pioneer in his field, the text is repleted with neologisms such as "hybridity", "cultural translation", "mimicry":

In the restless drive for cultural translation, hybrid sites of meaning open up a cleavage in the language of culture which suggests that the similitude of the symbol as it plays across cultural sites must not obscure the fact that repetition of the sign is, in each specific social practice, both different and differential [12];

Gibreel masquerades in the clothes of Rosa's dead husband, Sir Henry Diamond, ex-colonial landowner, and through his postcolonial mimicry, exacerbates the discursive split between the image of a continuist national history and the 'cracks and absences' that she knew herself to be [12].

Language tools provide an objective presentation of cognitive information, especially important for the scientific style texts, including monographs. For this type of text characterized by saturation of terms relating to postcolonial studies and intercultural communication, the following is true:

I want to take my stand on the shifting margins of cultural displacement - that confounds any profound or 'authentic' sense of a 'national' culture or an 'organic' intellectual - and ask what the function of a committed theoretical perspective might be, once the cultural and historical hybridity of the postcolonial world is taken as the paradigmatic place of departure [12].

In this text, there is language means that increase the density level of cognitive information: lexical reduction (etc., eg, ie, etc.); special terminological reduction, including innovative (CD, CS, DN, etc.):

How are subjects formed 'in-between', or in excess of, the sum of the 'parts' of difference (usually intoned as race/class/gender, etc.)? [12].

It should be noted the use of the names of famous scientists (Said, Spivak, etc.) to confirm the information and its citations:

As these images fade, and the empty eyes endlessly hold their menacing gaze, listen finally to Edward Said's attempt to historicize their chaos of identity [12].

Gayatri Spivak is right to conclude that it is 'in the interest of capital to preserve the comprador theatre in a state of relatively primitive labour legislation and environmental regulation' [12].

The lexical background of the rest of the language is neutral, that is also called general scientific vocabulary description. It is a written literary language norm, it also carries no emotional colouring.

A significant part of the vocabulary of scientific speech makes use of general scientific words that are used in different fields of knowledge (quantity, function, part, time, clause, act, etc.):

On the contrary, we are made excruciatingly aware of the ambivalent juxtaposition, the dangerous interstitial relation of the factual and the projective, and, beyond that, of the crucial function of the textual and the rhetorical [12]. 
It exists side by side with it - the one as an enabling part of the other - like the recto and verso of a sheet of paper, to use a common semiotic analogy in the uncommon context of politics [12].

The text of H.K. Bhabha's monograph has predominantly present the tense that can be observed, which is the absolute moment, so-called praesens generellis. Its use makes it possible to introduce the reported information as absolutely objective, outside the time (atemporal nature of the text):

Textuality is not simply a second-order ideological expression or a verbal symptom of a pre-given political subject [12].

The syntax of a text of monograph is characterized by a predominance of the common compound and complex sentences:

To demonstrate such an 'excess' is not merely to celebrate the joyous power of the signifier, Hybridity is the sign of the productivity of colonial power, its shifting forces and fixities; it is the name for the strategic reversal of the process of domination through disavowal (that is, the production of discriminatory identities that secure the 'pure' and original identity of authority) [12].

Additional means of the logical organization are graphical tools, especially font. Words and phrases, written in large print (DISSEMINATION. TIME, NARRATIVE AND THE MARGINS OF THE MODERN NATION), the words in italics (movement of signification, within the nation), the size and bold content of the font in headlines and subheads (Time, narrative and the margins of the modern nation the Time of the Nation) - all these means are the emphasizing of significant cognitive information.

Between parts of the statement, there is an ordered system of relations, the statement is consistent. The accuracy of presentation is achieved by using single-valued expressions. One can also note the use of quotes:

Translation passes through continua of transformation, not abstract ideas of identity and similarity. [Walter Benjamin, 1969.25] [12].

The text of H. K. Bhabha's monograph has one of the most distributed methods of reduction of the syntactic structure - aposiopesis (truncation), which is defined as incomplete, unsaid, interrupted proposals implying reliance on the reader guess. The use of aposiopesis is not a feature of scientific texts that make the H.K. Bhabha syntax special:

The 'beyond' is neither a new horizon, nor a leaving behind of the past.... Beginnings and endings may be the sustaining myths of the middle years; but in the fin de siecle we find ourselves in the moment of transit where space and time cross to produce complex figures of difference' and identity, past and present, inside and outside, inclusion and exclusion [12].

Another example of aposiopesis:

If Renee Green's questions open up an interrogatory, interstitial space between the act of representation Who...? What...? Where...? - and the presence of community itself, then consider her own creative intervention within this in-between moment [12].

In this example, we observe the omission of questions, because the author wants to give a reader an opportunity to ask them. This stylistic tool is able to establish a connection with the audience.

In the text of H.K. Bhabha's monograph, the category of deliberative is widely represented, such as parenthetic words and syntactic constructions expressing doubt, reflection, evaluation, etc.: it seems, no doubt, no wonder, in a sense, at best, at least, no wonder, etc.:

This seems to be the theoretical issue at the heart of Stuart Hall's arguments for the construction of a counterhegemonic power bloc through which a socialist party might construct its majority, its constituency: and the Labour Party might (in)conceivably improve its image [12].

The following example demonstrates the category of deliberative:

We have as yet no political theory, or theory of the subject, which is capable in this dialectical way of grasping social transformation as at once diffusion and affirmation, the death and birth of the subject - or at least we have no such theories that are not vacuously apocalyptic [12].

Thus, considering the communicative task of the text of H.K. Bhabha's monograph "The Location of Culture" that is to report new information about the post-colonial world order, it can be concluded that it is primary-cognitive, aided by the combination of the use of lexical and grammatical means by the author.

\section{Conclusion}

Social and cultural analysis of post-colonial discourse on the example of H.K. Bhabha monograph "The Location of Culture" reveals the following basic aspects of this phenomenon.

Post-colonialism is a critical theory, which aims to study the process of colonization from the perspective of the colonized societies. Post-colonialism comes into play in a social situation, which concerns the national culture after liberation from the imperial power. Post-colonialism is a style of thinking as the colonized and the colonizers, as well as methodological tools for the analysis of post-colonial discourse, its myths and history, language and landscape, "Self and Others".

H.K. Bhabha is a leader of the direction of postcolonial studies, an author of numerous neologisms (hybridity mimicry, etc.). Hybridity is a term used by H.K. Bhabha to describe and explain the ontological status of cultural objects generated in the course of convergence of European and colonial traditions in the age of globalization.

H.K. Bhabha focuses on translation as a means of cultural transfer in the post-colonial era of multiculturalism. In his view, a translator that speaks several languages is multicultural. However, H.K. Bhabha did not conclude on the translation of hybridity, but regards the process of interlingual and intercultural transfer as a way to hybrid semantic codes and actualizing their semantic verbal propositions in tissue and a socio-cultural situation of the target language. Linguistically, the text of the H.K. Bhabha's monograph "The Location of Culture" is a typical example of the humanitarian scientific functional style with a primarily-cognitive intentionality realized at the lexical (terms) and grammatical levels (aposiopesis, parenthentic design). 


\section{References}

1. A. Milostivaya, E. Nazarenko, I. Makhova, ASSEHR 97, 181-186 (2017)

2. M. Agar, Language \& Communication 31, 27-41 (2011)

3. P.F. Bandia, Translation as Reparation. Writing and Translation in Postcolonial Africa (Routledge, New York, 2014)

4. S. Bassnett, Translation Studies (Routledge, New York, 2002)

5. S. Bassnett, Translation Studies at Cross-roads, Target, 24.1, 15-25 (2012)

6. E. Federici, Remembering the Mothertongue in Another Language: Postcolonial Translation Studies (Labirinti, Trento, 2006)

7. F. Kalua, Journal of African Cultural Studies 21.1, 2332 (2009)

8. I.P. Fernández, Atlantis 31.2, 143-160 (2009)

9. G.K. Bhambra, Postcolonial Studies 17, 115-121 (2014)

10. R. Young, New Literary History 41.3, 19-42 (2012)

11. T. Shamma, MonTI 1, 183-196 (2009)

12. H.K. Bhabha, The Location of Culture (Routledge, London, 1994)

13. E. Said, Orientalism (Routledge, London, 2003)

14. M. Tymozcko, The Translator 1, 23-47 (2000)

15. G. Spivak, In Other Worlds (Methuen, London and New York, 1987) 